\title{
BMJ Open Descriptive study of sickness absence in Spanish regions in 2018: database study
}

\author{
Matilde Leonor Alba-Jurado, ${ }^{1}$ María José Aguado-Benedí, ${ }^{2}$ \\ Noelia Moreno-Morales, ${ }^{3}$ Maria Teresa Labajos-Manzanares, ${ }^{3}$ \\ Rocío Martín-Valero (iD ${ }^{3}$
}

\begin{abstract}
Objectives To provide a wide and thorough description of sickness absence (SA) in Spain, focussing on the different regions of the country and the main characteristics of $S A$. Methods A study of the SA spells in Spain, managed by the medical units of the National Institute of Social Security in 2018. The geographical scope of this observational study is the regions (Autonomous Community). Incidence, prevalence, and average duration SA in employees and self-employed are described. The study also describes the differences between non-work-related SA and workrelated SA. In age and sex variables, the incidence and the average duration are described. The average duration by Diagnostic Chapters (International Classification of Diseases, $10^{\text {th }}$ Revision (ICD-10)) and the highest number of SA spells by occupational activity and diagnosis are analysed.
\end{abstract}

Results A total of 540045 SA spells are analysed by non-work-related SA and 63441 by work-related SA. The national average prevalence in non-work-related SA spells is $32.98 / 1000$ among employed and $30.48 / 1000$ among self-employed; in work-related SA spells, the prevalence is $3.99 / 1000$. The national incidence in non-work-related SA spells is $24.8 / 1000$ for employees and $9.51 / 1000$ for selfemployed workers; in work-related SA spells the incidence is $3.55 / 1000$. The average duration is 58.67 days, with the longest duration being neoplasms and the shortest corresponding to infectious disease. The Community of Madrid shows the lowest prevalence, incidence and average duration in work-related SA. Influenza is the diagnosis that generates the largest number of SA spells. Activities of call centres and temporary employment agency activities are the occupations that have the highest number of SA spells.

Conclusions The biggest differences are found in the incidence and average duration, between the nonwork-related SA spells and work-related SA. If those characteristics of the SA in which a region is more in deficit are known, it will be possible to do better management of the SA.

Medical Inspector, Spain

${ }^{2}$ Director of Coordination of Medical Units, National Institute of Social Security, Madrid, Chief Medical Inspector, Spain

${ }^{3}$ Physiotherapy, University of Malaga Faculty of Health Sciences, Malaga, Spain

Correspondence to Dr Rocío Martín-Valero; rovalemas@gmail.com

\section{INTRODUCTION}

Sickness absence (SA) is one of the benefits of Social Security, included in article 169 of the Consolidated Text of the General Law of Social Security, RDL 8/2015 of $30^{\text {th }}$ October. It comprises benefits in kind (medical assistance) and monetary compensations

\section{Strengths and limitations of this study}

- The greatest strength of this study is the broad representativeness of its data.

- The data used are at a national level, which allows a great perspective of sickness absence (SA) in Spain.

- In this study, it has not always been possible to compare the data between employed and self-employed workers

- It has not always been possible to distinguish in this study between non-work-related and work-related in all SA spells.

- SA spells lasting less than 4 days has not been included in this study.

(benefits for SA). In Spain, there is a distinction between non-work-related SA (common disease and non-occupational accident) and work-related SA (professional illness and occupational accident). The differences between one group and the other can be seen both in the economic amount of the benefits due to sick leave and in the social security contributions. To be entitled to this subsidy, there must be medical examination and SA is certified by the family practitioner from the State Health Services, in case of common disease and non-occupational accident. If it is caused by occupational accidents or professional illness, this sick leave is certified by physicians ascribed to Insurance Companies linked to the Social Security system. Maximum duration of sick leave is 365 days, which can be extended for another 180 days if recovery and return of the worker to workplace are expected at that time. If the duration of sickness benefits has expired and the person's state of health has not improved enough to return to work, the worker may receive a disability pension. The maximum duration of SA benefits is similar to other countries nearby such as Germany, Belgium or Austria. However, there are considerable differences in all European Union countries 
in terms of the amount of the payment and the requirements for receiving these benefits. ${ }^{1}$

Concerning the rest of the countries of the Organisation for Economic Co-operation and Development (OECD), Spain is in an intermediate position regarding the SA days per worker/year. Mexico is in the highest position with 27.7 days, whereas Chile, in the lowest position, has 7.3 days. Spain has an average of 10.3 days, which is similar to the level of Austria and the Netherlands (10 days) (https://stats.oecd.org/index.aspx?queryid=30123).

Like most European countries, Spain's public sickness insurance spending is a major component of its social security system. ${ }^{1}$ The total financial cost of SA in consolidated Social Security budgets for 2019 in Spain reached $11554711.16 €$, which is $8.89 \%$ of the general Social Security budget. ${ }^{2}$ Besides, the importance of SA caused by disease or accident is not only determined by the social and financial costs that each State dedicates to it, ${ }^{3}$ but also by the resources that employers assign to it, ${ }^{4}$ as well as the productivity $\operatorname{losses}^{5}$ and the deterioration of these workers' health. ${ }^{6}$ It has been reported that work absenteeism due to illness is, in itself, a risk factor to fall sick, new periods of SA, unemployment, permanent disability pension, ${ }^{6-8}$ social exclusion ${ }^{9}$ and death. ${ }^{10-12}$ Long SA periods generate both an early retirement from the job market, a slower salary increase and an impoverishment of household wealth. ${ }^{6-9}$

Spain is divided into 17 regions. In each region there are significant differences in education, economic situation, unemployment rate and public health system. By sex, the percentage of men and women is balanced. The number of women is slightly higher, although the number of working men is still higher. By age, the regions with the youngest population are mainly those on the Mediterranean coast and also Castile La Mancha, Extremadura and the Community of Madrid. The northwestern regions are more aged.

In 2017 the working population rate in Spain was $59.41 \%$. The regions with the highest rates of active population were the Canary Islands, the Balearic Islands, the Community of Madrid and Catalonia and those with the lowest rates were the Cantabrian, Western and Central regions. Service sector was the majority of the workforce $(76 \%)$ in the islands, the Community of Madrid and Andalusia. Industry was the predominant sector in Navarre, the Basque Country and La Rioja; construction in Castile La Mancha; and agriculture and farming in Murcia (http://uvadoc.uva.es/handle/10324/26416)

These factors affect the behaviour of SA and their management in very different ways. It is important to know the differences to act accordingly.

Despite its relevance to public policies, there are few studies at the national level that describe the current situation of such benefits in our country; to date, the studies found in the literature related to this topic describe it partially ${ }^{13}$ in some provinces or specific areas, ${ }^{14}$ about some specific diseases ${ }^{15}$ or specific groups of workers. ${ }^{16}$ The used data are national, representing the whole of the workers in Spain. It is a comprehensive and representative study of the total of SA spells in our country in 2018.

The general objective of this study is to provide a wide description of SA in Spain, focussing on the different regions of the country and according to the main characteristics of SA and differences between regions.

The specific objectives would be the description of the incidence, prevalence and average duration of SA; the description of the average duration and incidence rate about age and sex, as well as the average duration of SA by Diagnostic Chapters following the International Classification of Diseases, $10^{\text {th }}$ Revision (ICD-10). The main occupational activities in which there are more workers with SA spells and the main diseases that cause more SA spells.

\section{MATERIAL AND METHODS}

This study is carried out using the statistical databases provided by the Spanish National Institute of Social Security (INSS), which are published on the website of this organisation (www.seg-social.es/wps/portal/wss/ internet/EstadisticasPresupuestosEstudios/), and databases obtained from specific programmes used by the Medical Units.

The reference population is formed by all the workers in Spain covered by the Social Security system in the year 2018. The study excludes the SA cases of Civil workers of the State, Armed Forces personnel and workers of the General Judicial Benefit Society, whose control and management are not an object of study. SA spells with a duration of fewer than 4 days are not included, because they do not obtain economic benefits from the Social Security system in Spain. Our study does not include unemployed workers, because they do not receive SA benefits

In Spain, our system of social security is contributory. To this end, both the worker and the company contribute to the system every month a sum of money (contribution) so that the worker can obtain benefits in case of illness or accident. If the worker is self-employed, it is himself who makes these economic contributions exclusively for nonwork-related SA. This self-employed person also can pay voluntarily an extra amount for work-related SA to obtain benefits if he or she has a professional illness or an occupational accident.

Our database does not distinguish between employed and self-employed workers in the case of work-related SA. However, in non-work-related SA such division is made (table 1)

Sample: The 2018 total SA records of the INSS is used, which coincide with the total population studied.

The variables used were: Age (in ranges), sex, average SA duration, diagnosis and diagnostic group (ICD10), employee or self-employed, non-work-related SA (common disease non-occupational accident) or work-related SA (occupational accident and professional illness), and occupations with higher SA ranking 

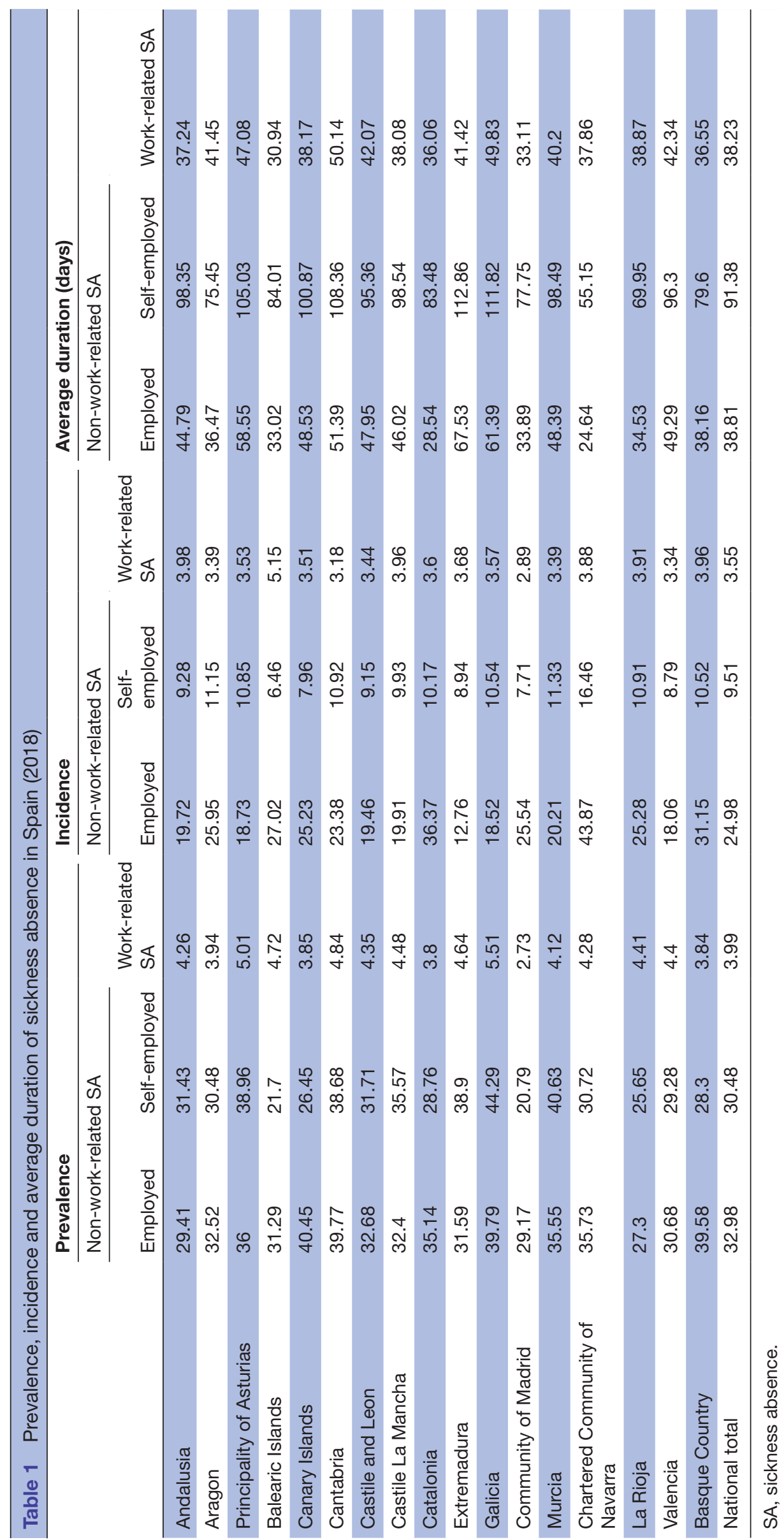
according to the International Standard Industrial Classification of all Economic Activities (ISIC Rev-4).

The geographical scope of the study is the regions of Spain.

This is an observational study. The statistical calculations used to refer to all the people affiliated with the system who are entitled to receive the SA benefit (AFI), calculated according to the data provided by the Public Employment Service, the General Treasury of Social Security, INSS and the Social Institute of the Navy.

Incidence: The ratio that calculates the number of SA (MP2R) per 1000 affiliates. To compute the SA, the number of real registrations for the benefit (MP2R) is used. Monthly datum: MP2R $\times 1000 /$ AFI. Accumulated datum: average $($ MP2R $) \times 1000 /$ AFI.

Prevalence: The ratio that calculates the number of SA processes in force per 1000 affiliates. To compute the processes in force, the number of perceivers at the end of the period (MP4) is used. Monthly datum: MP4 $\times 1000$ / AFI. Accumulated datum: average (MP4) $\times 1000 /$ AFI.

The mean general duration is the average of all durations per year. The mean duration per age range and sex were calculated by dividing the number of days in SA by the number of workers in SA in that range. It is also described the number of workers in SA per 1000 affiliates. The median for the average duration per diagnostic chapter is calculated, using the statistics software Excel.

\section{Patient and public involvement}

Anonymised patient data are used in this study. Patients and members of the public are not involved in the conducting of the study.

\section{RESULTS}

A total of 540045 non-work-related SA spells and 63 441 work-related SA spells is analysed, which are those controlled by the Medical Units of the Spanish National Institute of Social Security. There is a total of 16373239 workers affiliated to social security.

The age of the study participants is 16 to 70 years old, both men and women. All are included in all the variables studied (non-work-related, work-related, employed, self-employed, sex, age, diagnosis and occupational activities). Follow-up time is 1 year (2018).

Our results are:

\section{SA prevalence}

The prevalence of non-work-related SA is 32.68/1000, among employed and 30.48/1000 among self-employed. Prevalence of work-related is $3.99 / 1000$. In the nonwork-related, it ranges between 27.3 in La Rioja and 40.45 in the Canary Islands in employed persons. In selfemployed, it ranges between 21.5 in the Balearic Islands and 40.63 in the Region of Murcia. In work-related SA, it ranges from 2.73 in the Community of Madrid to 5.51 in Galicia (table 1).

\section{SA incidence}

Incidence of non-work-related was 24.87/1000 among employed and 9.51/1000 among self-employed. The incidence of work-related was 3.55/1000. Its values ranged between 12.76 in Extremadura and 36.7 in Catalonia (non-work-related, employed person); for self-employed it ranged between 7.71 in Community of Madrid and 16.46 in Chartered Community of Navarre (non-workrelated SA). In work-related SA, it ranged from 2.89 in Madrid to 5.15 in the Balearic Islands (table 1).

\section{Average SA duration}

The average duration of SA was 58.67 days (in non-workrelated SA from 38.81 days among employed to 91.38 days among self-employed) with a median of 48.53 days. In non-work-related SA for employees, it ranged between 24.64 days in Chartered Community of Navarre to 67.53 in Extremadura. For self-employed, it varied between 55.15 days in Navarra to 112.86 days in Extremadura. In work-related SA, it ranged from 30.94 days in the Balearic Islands to 50.14 in Cantabria (table 1).

\section{SA spells and average duration (age ranges and sex)}

In table 2, the total number of workers on sick leave by age and sex is analysed. There is a distinction between the absolute number of workers on SA and the number of workers on SA per 1000 affiliated per age group and gender because in Spain, in almost all age groups there are more men than women affiliated to social security. This may result in more absolute numbers of sickness absence for men, although the number of SA is higher for women according to the number of affiliates.

Therefore, the total number of workers in SA by age and sex is higher in men than in women (table 2). According to age range and sex, the number of affiliates in SA is higher in women, except in Castilla and Leon, Chartered Community of Navarre and the Basque Country between 16 and 25 years of age, Principality of Asturias and La Rioja between 26 and 35 years and La Rioja in 36 to 45 and 46 to 55 years.

The average duration of SA is also higher in women than in men in all the age ranges, except in the Community of Madrid and La Rioja for 16 to 25 years, and Principality of Asturias, Balearic Islands, Canary Islands, Catalonia and Chartered Community of Navarre in workers over 65 years of age.

In women, the average duration of $\mathrm{SA}$ is 58.5 days (minimum 12 and maximum 137), with a median of 52 days. In men, the average is 53.08 days (minimum 13 and maximum 118), with a median of 44 .

\section{Average SA duration (diagnostic chapter)}

The average SA duration, in general, is 56.82 days, with a median of 52.80 days. In all the regions Communities, the longest duration corresponds to neoplasms, followed by heart diseases and mental disorders. The shortest duration corresponds to infectious diseases (table 3). 


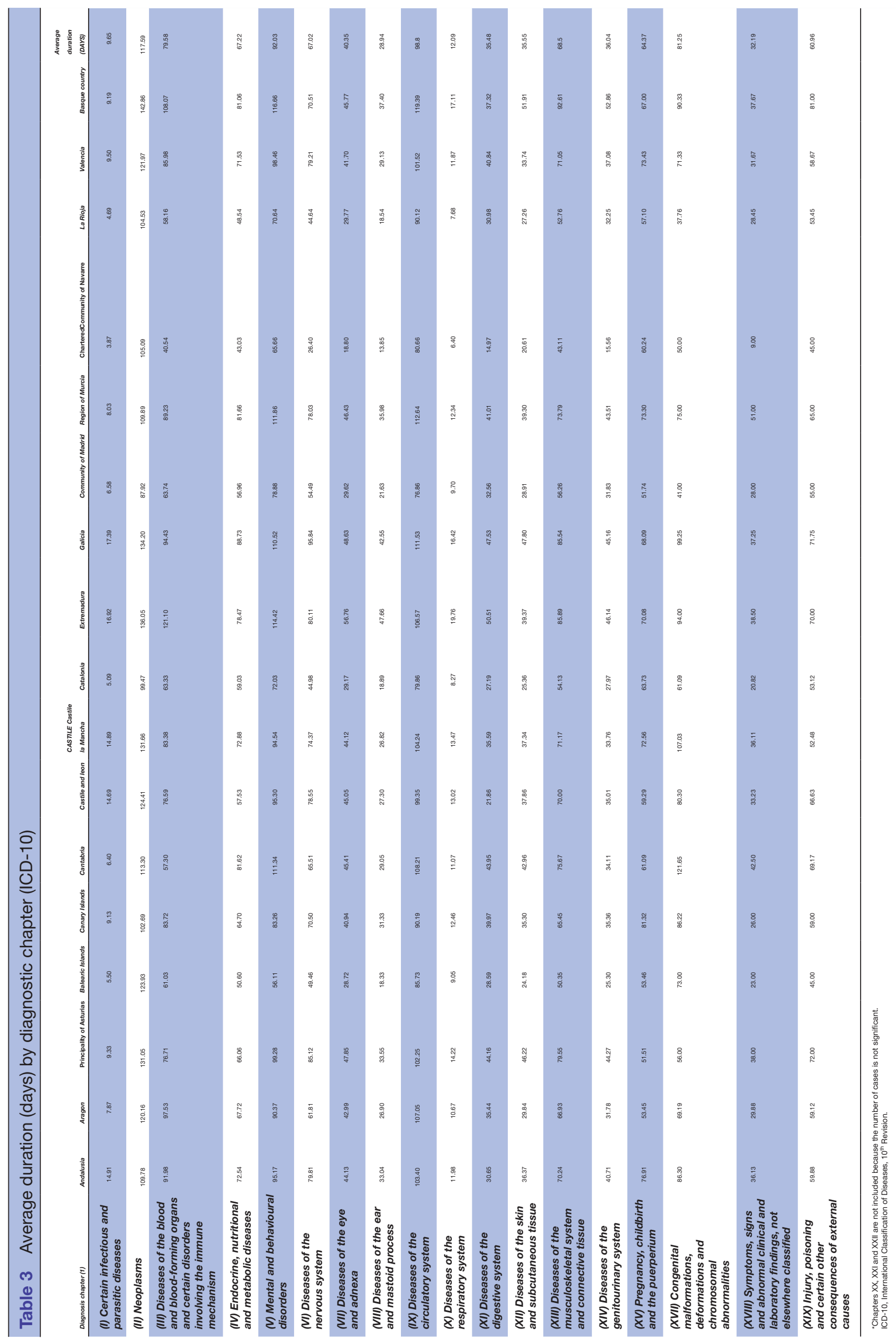

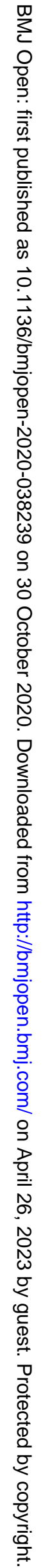


Table 4 Sickness absence spells by diagnosis (ICD-10)

\begin{tabular}{|c|c|c|c|}
\hline $\begin{array}{l}\text { Autonomous community } \\
\text { of Spain }\end{array}$ & Code & Diagnosis & $\begin{array}{l}\text { SA /1000 affiliates/ } \\
\text { per month }\end{array}$ \\
\hline \multirow{8}{*}{ Andalusia } & M54.5 & Low back pain & 1.36 \\
\hline & K52 & Other non-infective gastroenteritis and colitis & 1.00 \\
\hline & J00 & Acute nasopharyngitis (common cold) & 0.83 \\
\hline & $\mathrm{J} 11$ & Influenza, virus not identified & 0.82 \\
\hline & M54.2 & Cervicalgia & 0.57 \\
\hline & M54.3 & Sciatica & 0.52 \\
\hline & J02.9 & Acute pharyngitis, unspecified & 0.40 \\
\hline & J03.9 & Acute tonsillitis, unspecified & 0.38 \\
\hline \multirow[t]{8}{*}{ Aragon } & K52.9 & Non-infective gastroenteritis and colitis, unspecified & 1.94 \\
\hline & J11 & Influenza, virus not identified & 1.28 \\
\hline & M54.5 & Low back pain & 1.16 \\
\hline & J02.9 & Acute pharyngitis, unspecified & 0.97 \\
\hline & M25 & Other joint disorders, not elsewhere classified & 0.76 \\
\hline & M54.3 & Sciatica & 0.42 \\
\hline & M54.2 & Cervicalgia & 0.41 \\
\hline & F41 & Other anxiety disorders & 0.38 \\
\hline \multirow[t]{8}{*}{ Principality of Asturias } & K52.9 & Non-infective gastroenteritis and colitis, unspecified & 1.03 \\
\hline & M54.5 & Low back pain & 0.83 \\
\hline & F41 & Other anxiety disorders & 0.80 \\
\hline & J11 & Influenza, virus not identified & 0.55 \\
\hline & M54.3 & Sciatica & 0.46 \\
\hline & M54.2 & Cervicalgia & 0.40 \\
\hline & J02.9 & Acute pharyngitis, unspecified & 0.30 \\
\hline & M23 & Internal derangement of knee & 0.29 \\
\hline \multirow[t]{8}{*}{ Balearic Islands } & K52.9 & Non-infective gastroenteritis and colitis, unspecified & 2.29 \\
\hline & M54.5 & Low back pain & 1.61 \\
\hline & B97.8 & $\begin{array}{l}\text { Other viral agents as the cause of diseases classified to } \\
\text { other chapters }\end{array}$ & 1.26 \\
\hline & J11 & Influenza, virus not identified & 1.15 \\
\hline & F41.9 & Anxiety disorder, unspecified & 0.77 \\
\hline & J03.9 & Acute tonsillitis, unspecified & 0.72 \\
\hline & $\mathrm{J} 00$ & Acute nasopharyngitis (common cold) & 0.60 \\
\hline & M54.3 & Sciatica & 0.60 \\
\hline \multirow[t]{8}{*}{ Canary Islands } & M54.5 & Low back pain & 1.40 \\
\hline & J11 & Influenza, virus not identified & 1.16 \\
\hline & K52.9 & Non-infective gastroenteritis and colitis, unspecified & 1.02 \\
\hline & $\mathrm{J} 00$ & Acute nasopharyngitis (common cold) & 0.82 \\
\hline & J20.9 & Acute bronchitis, unspecified & 0.59 \\
\hline & F06.4 & Organic anxiety disorder & 0.57 \\
\hline & M54.3 & Sciatica & 0.51 \\
\hline & M54.2 & Cervicalgia & 0.44 \\
\hline \multirow[t]{3}{*}{ Cantabria } & K52.9 & Non-infective gastroenteritis and colitis, unspecified & 1.64 \\
\hline & J11 & Influenza, virus not identified & 1.13 \\
\hline & M54.5 & Low back pain & 0.98 \\
\hline
\end{tabular}

Continued 
Table 4 Continued

\begin{tabular}{|c|c|c|c|}
\hline $\begin{array}{l}\text { Autonomous community } \\
\text { of Spain }\end{array}$ & Code & Diagnosis & $\begin{array}{l}\text { SA /1000 affiliates/ } \\
\text { per month }\end{array}$ \\
\hline & R45 & Symptoms and signs involving emotional state & 0.69 \\
\hline & J02.9 & Acute pharyngitis, unspecified & 0.67 \\
\hline & J06 & $\begin{array}{l}\text { Acute upper respiratory infections of multiple and } \\
\text { unspecified sites }\end{array}$ & 0.66 \\
\hline & M54.3 & Sciatica & 0.61 \\
\hline & M54.2 & Cervicalgia & 0.57 \\
\hline \multirow[t]{8}{*}{ Castile and Leon } & M54.5 & Low back pain & 1.28 \\
\hline & J11 & Influenza, virus not identified & 0.86 \\
\hline & F41.9 & Anxiety disorder, unspecified & 0.53 \\
\hline & M54.3 & Sciatica & 0.52 \\
\hline & J98.8 & Other specified respiratory disorders & 0.40 \\
\hline & J06.9 & Acute upper respiratory infection, unspecified & 0.37 \\
\hline & $\mathrm{J} 00$ & Acute nasopharyngitis (common cold) & 0.30 \\
\hline & K52 & Other non-infective gastroenteritis and colitis & 0.10 \\
\hline \multirow[t]{8}{*}{ Castile La Mancha } & M54.5 & Low back pain & 1.22 \\
\hline & K52.9 & Non-infective gastroenteritis and colitis, unspecified & 0.79 \\
\hline & J00 & Acute nasopharyngitis (common cold) & 0.62 \\
\hline & J11 & Influenza, virus not identified & 0.53 \\
\hline & K52 & Other non-infective gastroenteritis and colitis & 0.50 \\
\hline & J03.9 & Acute tonsillitis, unspecified & 0.43 \\
\hline & M54.2 & Cervicalgia & 0.39 \\
\hline & M54.3 & Sciatica & 0.37 \\
\hline \multirow[t]{8}{*}{ Catalonia } & K52.9 & Non-infective gastroenteritis and colitis, unspecified & 2.82 \\
\hline & J00 & Acute nasopharyngitis (common cold) & 2.09 \\
\hline & M54.5 & Low back pain & 1.96 \\
\hline & $\mathrm{J} 11$ & Influenza, virus not identified & 1.58 \\
\hline & F41.9 & Anxiety disorder, unspecified & 1.40 \\
\hline & B97.8 & $\begin{array}{l}\text { Other viral agents as the cause of diseases classified to } \\
\text { other chapters }\end{array}$ & 1.05 \\
\hline & J03.9 & Acute tonsillitis, unspecified & 0.85 \\
\hline & M54.2 & Cervicalgia & 0.68 \\
\hline \multirow[t]{8}{*}{ Extremadura } & M54.5 & Low back pain & 0.76 \\
\hline & $\mathrm{J} 11$ & Influenza, virus not identified & 0.49 \\
\hline & S93 & $\begin{array}{l}\text { Dislocation, sprain and strain of joints and ligaments at } \\
\text { ankle and foot level }\end{array}$ & 0.28 \\
\hline & M54.2 & Cervicalgia & 0.23 \\
\hline & M54.3 & Sciatica & 0.20 \\
\hline & F41 & Other anxiety disorders & 0.18 \\
\hline & M54.9 & Dorsalgia, unspecified & 0.17 \\
\hline & M75 & Shoulder lesions & 0.14 \\
\hline \multirow[t]{5}{*}{ Galicia } & M54.5 & Low back pain & 1.19 \\
\hline & $\mathrm{J} 11$ & Influenza, virus not identified & 0.94 \\
\hline & M54.2 & Cervicalgia & 0.47 \\
\hline & F41 & Other anxiety disorders & 0.44 \\
\hline & $\mathrm{J} 20.9$ & Acute bronchitis, unspecified & 0.42 \\
\hline
\end{tabular}

Continued 
Table 4 Continued

\begin{tabular}{|c|c|c|c|}
\hline $\begin{array}{l}\text { Autonomous community } \\
\text { of Spain }\end{array}$ & Code & Diagnosis & $\begin{array}{l}\text { SA /1000 affiliates/ } \\
\text { per month }\end{array}$ \\
\hline & M54.3 & Sciatica & 0.30 \\
\hline & S93 & $\begin{array}{l}\text { Dislocation, sprain and strain of joints and ligaments at } \\
\text { ankle and foot level }\end{array}$ & 0.24 \\
\hline \multirow[t]{5}{*}{ Community of Madrid } & K52.9 & Non-infective gastroenteritis and colitis, unspecified & 1.51 \\
\hline & $\mathrm{F} 41$ & Other anxiety disorders & 0.76 \\
\hline & J02.9 & Acute pharyngitis, unspecified & 0.67 \\
\hline & $\mathrm{J} 11$ & Influenza, virus not identified & 0.53 \\
\hline & M25 & Other joint disorders, not elsewhere classified & 0.48 \\
\hline & J11 & Influenza, virus not identified & 1.16 \\
\hline & M54.5 & Low back pain & 1.13 \\
\hline & J02.9 & Acute pharyngitis, unspecified & 0.82 \\
\hline & M54.3 & Sciatica & 0.69 \\
\hline & $\mathrm{R} 45$ & Symptoms and signs involving emotional state & 0.62 \\
\hline & M54.2 & Cervicalgia & 0.55 \\
\hline & J06.9 & Acute upper respiratory infection, unspecified & 0.41 \\
\hline \multirow{2}{*}{$\begin{array}{l}\text { Chartered Community of } \\
\text { Navarre }\end{array}$} & K52.9 & Non-infective gastroenteritis and colitis, unspecified & 3.08 \\
\hline & F41.9 & Anxiety disorder, unspecified & 0.89 \\
\hline \multirow[t]{8}{*}{ La Rioja } & K52.9 & Non-infective gastroenteritis and colitis, unspecified & 2.20 \\
\hline & J00 & Acute nasopharyngitis (common cold) & 1.42 \\
\hline & $\mathrm{J} 11$ & Influenza, virus not identified & 1.14 \\
\hline & M54.5 & Low back pain & 1.10 \\
\hline & M54.3 & Sciatica & 0.56 \\
\hline & J06.9 & Acute upper respiratory infection, unspecified & 0.39 \\
\hline & M25.5 & Pain in joint & 0.36 \\
\hline & $\mathrm{R} 45.0$ & Nervousness & 0.35 \\
\hline \multirow[t]{7}{*}{ Valencia } & M54.5 & Low back pain & 1.04 \\
\hline & J11 & Influenza, virus not identified & 0.85 \\
\hline & F41.9 & Anxiety disorder, unspecified & 0.56 \\
\hline & K52.9 & Non-infective gastroenteritis and colitis, unspecified & 0.55 \\
\hline & J00 & Acute nasopharyngitis (common cold) & 0.45 \\
\hline & M54.2 & Cervicalgia & 0.39 \\
\hline & M54.3 & Sciatica & 0.33 \\
\hline
\end{tabular}


Table 4 Continued

\begin{tabular}{llll}
\hline $\begin{array}{l}\text { Autonomous community } \\
\text { of Spain }\end{array}$ & Code & Diagnosis & $\begin{array}{l}\text { SA /1000 affiliates/ } \\
\text { per month }\end{array}$ \\
\hline & J20.9 & Acute bronchitis, unspecified & 0.32 \\
\hline Basque Country & M54.5 & Low back pain & 1.83 \\
& M54.2 & Cervicalgia & 1.68 \\
& J00 & Acute nasopharyngitis (common cold) & 0.91 \\
\hline K52.9 & Non-infective gastroenteritis and colitis, unspecified & 0.75 \\
& J11 & Influenza, virus not identified & 0.63 \\
& F43.2 & Adjustment disorders & 0.56 \\
\hline F41.9 & Anxiety disorder, unspecified & 0.49 \\
\hline R10 & Abdominal and pelvic pain & 0.35 \\
\hline
\end{tabular}

ICD-10, International Classification of Diseases, $10^{\text {th }}$ Revision; SA, sickness absence.

\section{SA spells by ICD-10 diagnosis}

Table 4 describes the main diagnoses that generate the highest numbers of SA spells/1000 affiliates/per month. The diagnoses with the highest number of SA were: Influenza, virus not identified, lower back pain and noninfective gastroenteritis and colitis, unspecified. They highlighted the multiple SA spells per non-infective gastroenteritis and colitis diagnosis, unspecific on Catalonia, Balearic Islands and Community of Navarre.

\section{SA spells by ISIC Rev-4}

There is an outstanding number of SA spell in general public administration activities, hospital activities, retail sale in non-specialised stores with food, beverages or tobacco predominating and general cleaning of buildings (table 5).

However, when these cases are analysed by the number of affiliates in each occupational activities, those occupations in which the most SA spells is found are activities of call centres, temporary employment agency activities and general public administration activities.

\section{DISCUSSION}

The obtained results confirm many of the findings described by other authors at both the national ${ }^{17}$ and international levels. ${ }^{18}$

The prevalence and incidence are much higher in non-work-related SA than in work-related SA, which is logical, since work-related SA only included the accidents occurred in the workplace, as well as the professional diseases described in the Royal Decree 1299/2006 of $10^{\text {th }}$ November, and not all diseases, accidents and injuries that any worker can suffer from. Conversely, in the case of non-work-related SA all illness and accidents are included.

When the SA prevalence in each region is analysed, it is observed that there are few regions, such as Aragon and the Community of Madrid, below the national average. By breaking it down into non-work-related SA, the regions that are below the average were Andalusia, Aragon, the Balearic Island, Community of Madrid, La Rioja and Valencian Community, while in work-related SA, Aragon, Catalonia, the Basque Country, the Canary Islands and Community of Madrid stand out below the average. It is difficult to know the reasons for these differences in the prevalence SA. To analyse the possible causes of these differences, it would be necessary to carry out other sorts of studies.

There are also important differences concerning incidence, with these differences being very marked in some regions. Only Castile and Leon does not reach the national average. In the case of non-work-related SA, Andalusia, Castile and Leon, Extremadura and Valencian Community are below the national average. In work-related SA, values are very approximate in all regions. The highest value is in the Balearic Islands.

There is a significant difference in the incidence of SA between the employed and self-employed which was much higher in the former. This is in line with the results obtained in other studies conducted in Spain ${ }^{4}$ and at an international level. ${ }^{71920}$ The self-employed are only charging for the work they have done. On the other hand, if they are in SA's position, the amount they receive is lower, because it depends on their contributions to the social security system.

The average duration is shorter in all regions in the case of work-related SA because these SA are managed directly by associated insurance companies, whose network of doctors and hospital beds are exclusively for workers who had suffered occupational accidents or professional illness. In the case of non-work-related SA, healthcare is provided by the Public Health System, where other patients are also treated (children, elderly, non-working patients, and so on) and, therefore, waiting lists were longer and treatments for these patients could be delayed further. Besides, the longest duration is for oncological diseases and mental disorders, the origin of which is usually unrelated to work. This finding is in line 
Table 5 Sickness absence situations by occupational activities (International Standard Industrial Classification of all Economic Activities, ISIC Rev-4)

\begin{tabular}{|c|c|c|c|c|}
\hline $\begin{array}{l}\text { Autonomous } \\
\text { community }\end{array}$ & Code & Occupational activities & SA spells & SA/1000 affiliates \\
\hline \multirow[t]{10}{*}{ Andalusia } & 8411 & General public administration activities & 61457 & 30.84 \\
\hline & 8610 & Hospital activities & 40544 & 20.30 \\
\hline & 8121 & General cleaning of buildings & 23802 & 18.89 \\
\hline & 5610 & Restaurants and mobile food service activities & 23377 & 28.5 \\
\hline & 5630 & Beverage serving activities & 20659 & 10.74 \\
\hline & 4100 & Construction of buildings & 16608 & 10.22 \\
\hline & 4711 & $\begin{array}{l}\text { Retail sale in non-specialised stores with food, } \\
\text { beverages or tobacco predominating }\end{array}$ & 16253 & 9 \\
\hline & 5510 & Hotels and similar accommodation & 16061 & 20.05 \\
\hline & 4630 & Wholesale of food, beverage and tobacco & 15010 & 9.72 \\
\hline & 8220 & Activities of call centres & 14652 & 69.07 \\
\hline \multirow[t]{10}{*}{ Aragon } & 8411 & General public administration activities & 9685 & 23.30 \\
\hline & 8610 & Hospital activities & 8022 & 16.61 \\
\hline & 7820 & Temporary employment agency activities & 7550 & 73.50 \\
\hline & 2930 & $\begin{array}{l}\text { Manufacture of parts and accessories of motor } \\
\text { vehicles }\end{array}$ & 5874 & 11.70 \\
\hline & 8121 & General cleaning of buildings & 5464 & 21.78 \\
\hline & 4711 & $\begin{array}{l}\text { Retail sale in non-specialised stores with food, } \\
\text { beverages or tobacco predominating }\end{array}$ & 3773 & 5.3 \\
\hline & 5610 & Restaurants and mobile food service activities & 3669 & 28.5 \\
\hline & 8220 & Activities of call centres & 3459 & 43 \\
\hline & 4923 & Freight transport by road & 3214 & 15.57 \\
\hline & 5630 & Beverage serving activities & 3073 & 10.95 \\
\hline \multirow{10}{*}{$\begin{array}{l}\text { Principality of } \\
\text { Asturias }\end{array}$} & 8610 & Hospital activities & 6422 & 20.65 \\
\hline & 4711 & $\begin{array}{l}\text { Retail sale in non-specialised stores with food, } \\
\text { beverages or tobacco predominating }\end{array}$ & 5217 & 9.56 \\
\hline & 8411 & General public administration activities & 4000 & 19.21 \\
\hline & 5630 & Beverage serving activities & 2560 & 10.46 \\
\hline & 2410 & Manufacture of basic iron and steel & 2330 & 12.08 \\
\hline & 8121 & General cleaning of buildings & 2285 & 13.6 \\
\hline & 5610 & Restaurants and mobile food service activities & 2047 & 22.45 \\
\hline & 8730 & $\begin{array}{l}\text { Residential care activities for the elderly and } \\
\text { disabled }\end{array}$ & 1950 & 20.82 \\
\hline & 8122 & Other building and industrial cleaning activities & 1651 & 18 \\
\hline & 9700 & $\begin{array}{l}\text { Activities of households as employers of domestic } \\
\text { personnel }\end{array}$ & 1365 & 8.51 \\
\hline \multirow[t]{7}{*}{ Balearic Islands } & 5510 & Hotels and similar accommodation & 19736 & 30.31 \\
\hline & 5610 & Restaurants and mobile food service activities & 9399 & 13.6 \\
\hline & 8610 & Hospital activities & 8059 & 26.49 \\
\hline & 8411 & General public administration activities & 6141 & 27.19 \\
\hline & 4100 & Construction of buildings & 6129 & 13 \\
\hline & 4711 & $\begin{array}{l}\text { Retail sale in non-specialised stores with food, } \\
\text { beverages or tobacco predominating }\end{array}$ & 5078 & 8.44 \\
\hline & 5630 & Beverage serving activities & 4740 & 8.32 \\
\hline
\end{tabular}

Continued 
Table 5 Continued

\begin{tabular}{|c|c|c|c|c|}
\hline $\begin{array}{l}\text { Autonomous } \\
\text { community }\end{array}$ & Code & Occupational activities & SA spells & SA/1000 affiliates \\
\hline & 8121 & General cleaning of buildings & 4125 & 16.70 \\
\hline & 5520 & Short-term accommodation activities & 3034 & 12.56 \\
\hline & 4751 & Retail sale of textiles in specialised stores & 2408 & 21.6 \\
\hline \multirow[t]{10}{*}{ Canary Islands } & 5510 & Hotels and similar accommodation & 26147 & 43.13 \\
\hline & 8610 & Hospital activities & 16865 & 30.7 \\
\hline & 8411 & General public administration activities & 15899 & 31.59 \\
\hline & 5610 & Restaurants and mobile food service activities & 11628 & 18.32 \\
\hline & 4711 & $\begin{array}{l}\text { Retail sale in non-specialised stores with food, } \\
\text { beverages or tobacco predominating }\end{array}$ & 10495 & 7.9 \\
\hline & 5520 & Short-term accommodation activities & 7221 & 32.30 \\
\hline & 8121 & General cleaning of buildings & 7000 & 18.7 \\
\hline & 5630 & Beverage serving activities & 5507 & 8.36 \\
\hline & 4100 & Construction of buildings & 5414 & 11.70 \\
\hline & 8521 & General secondary education & 5340 & 12.13 \\
\hline \multirow[t]{10}{*}{ Cantabria } & 8411 & General public administration activities & 3851 & 28.5 \\
\hline & 7820 & Temporary employment agency activities & 3612 & 76.53 \\
\hline & 8610 & Hospital activities & 3492 & 20.09 \\
\hline & 8121 & General cleaning of buildings & 1828 & 17.11 \\
\hline & 5610 & Restaurants and mobile food service activities & 1616 & 22.5 \\
\hline & 5630 & Beverage serving activities & 1383 & 10.97 \\
\hline & 8220 & Activities of call centres & 1170 & 60 \\
\hline & 8521 & General secondary education & 1170 & 8.38 \\
\hline & 4791 & Retail sale via mail order houses or via Internet & 1023 & 16.8 \\
\hline & 8620 & Medical and dental practice activities & 998 & 32 \\
\hline \multirow[t]{10}{*}{ Castile and Leon } & 8411 & General public administration activities & 9940 & 16.89 \\
\hline & 8610 & Hospital activities & 9741 & 12.04 \\
\hline & 8220 & Activities of call centres & 8920 & 85.14 \\
\hline & 8121 & General cleaning of buildings & 7489 & 17.87 \\
\hline & 4711 & $\begin{array}{l}\text { Retail sale in non-specialised stores with food, } \\
\text { beverages or tobacco predominating }\end{array}$ & 5953 & 7.94 \\
\hline & 8790 & Other residential care activities & 5089 & 21.95 \\
\hline & 5630 & Beverage serving activities & 5023 & 14.59 \\
\hline & 7820 & Temporary employment agency activities & 4676 & 45.75 \\
\hline & 5610 & Restaurants and mobile food service activities & 4493 & 24.90 \\
\hline & 2910 & Manufacture of motor vehicles & 4409 & 10.35 \\
\hline \multirow{8}{*}{$\begin{array}{l}\text { Castile La } \\
\text { Mancha }\end{array}$} & 8411 & General public administration activities & 15003 & 22.17 \\
\hline & 8610 & Hospital activities & 7820 & 14.89 \\
\hline & 8121 & General cleaning of buildings & 5363 & 19.98 \\
\hline & 7820 & Temporary employment agency activities & 5272 & 56.70 \\
\hline & 5210 & Warehousing and storage & 5251 & 60 \\
\hline & 4100 & Construction of buildings & 4479 & 8.94 \\
\hline & 4711 & $\begin{array}{l}\text { Retail sale in non-specialised stores with food, } \\
\text { beverages or tobacco predominating }\end{array}$ & 4267 & 5.06 \\
\hline & 5610 & Restaurants and mobile food service activities & 4092 & 32.54 \\
\hline
\end{tabular}

Continued 
Table 5 Continued

\begin{tabular}{|c|c|c|c|c|}
\hline $\begin{array}{l}\text { Autonomous } \\
\text { community }\end{array}$ & Code & Occupational activities & SA spells & SA/1000 affiliates \\
\hline & 4923 & Freight transport by road & 3846 & 14.08 \\
\hline & 5630 & Beverage serving activities & 3526 & 10.62 \\
\hline \multirow[t]{10}{*}{ Catalonia } & 8610 & Hospital activities & 75958 & 32.68 \\
\hline & 8411 & General public administration activities & 70569 & 32.11 \\
\hline & 5610 & Restaurants and mobile food service activities & 45084 & 47 \\
\hline & 8121 & General cleaning of buildings & 44117 & 22.8 \\
\hline & 7820 & Temporary employment agency activities & 43109 & 73.56 \\
\hline & 8220 & Activities of call centres & 37877 & 74.91 \\
\hline & 4711 & $\begin{array}{l}\text { Retail sale in non-specialised stores with food, } \\
\text { beverages or tobacco predominating }\end{array}$ & 30528 & 12.95 \\
\hline & 4751 & Retail sale of textiles in specialised stores & 24417 & 10.36 \\
\hline & 8812 & $\begin{array}{l}\text { Social work activities without accommodation for } \\
\text { the elderly and disabled }\end{array}$ & 20007 & 43.56 \\
\hline & 8423 & Public order and safety activities & 19807 & 65 \\
\hline \multirow[t]{10}{*}{ Extremadura } & 8411 & General public administration activities & 10813 & 23.68 \\
\hline & 8610 & Hospital activities & 5921 & 17.95 \\
\hline & 8121 & General cleaning of buildings & 2007 & 19.56 \\
\hline & 8812 & $\begin{array}{l}\text { Social work activities without accommodation for } \\
\text { the elderly and disabled }\end{array}$ & 1643 & 18 \\
\hline & 4100 & Construction of buildings & 1610 & 7.48 \\
\hline & 5630 & Beverage serving activities & 1599 & 10.55 \\
\hline & 4711 & $\begin{array}{l}\text { Retail sale in non-specialised stores with food, } \\
\text { beverages or tobacco predominating }\end{array}$ & 1136 & 3.98 \\
\hline & 5610 & Restaurants and mobile food service activities & 1044 & 13.64 \\
\hline & 4923 & Freight transport by road & 914 & 12.89 \\
\hline & 0150 & Mixed farming & 902 & 8.79 \\
\hline \multirow[t]{10}{*}{ Galicia } & 8610 & Hospital activities & 12552 & 16.6 \\
\hline & 8411 & General public administration activities & 12137 & 19.12 \\
\hline & 4711 & $\begin{array}{l}\text { Retail sale in non-specialised stores with food, } \\
\text { beverages or tobacco predominating }\end{array}$ & 7498 & 6.4 \\
\hline & 5630 & Beverage serving activities & 6532 & 12 \\
\hline & 8121 & General cleaning of buildings & 5775 & \\
\hline & 7820 & Temporary employment agency activities & 5270 & 40.61 \\
\hline & 9700 & $\begin{array}{l}\text { Activities of households as employers of domestic } \\
\text { personnel }\end{array}$ & 4830 & 11.45 \\
\hline & 5610 & Restaurants and mobile food service activities & 4664 & 17.6 \\
\hline & 8220 & Activities of call centres & 4558 & 47.19 \\
\hline & 4100 & Construction of buildings & 3622 & 5.27 \\
\hline \multirow{6}{*}{$\begin{array}{l}\text { Community of } \\
\text { Madrid }\end{array}$} & 8610 & Hospital activities & 44482 & 17.65 \\
\hline & 8121 & General cleaning of buildings & 42703 & 20.63 \\
\hline & 5610 & Restaurants and mobile food service activities & 36939 & 28.54 \\
\hline & 4711 & General public administration activities & 35475 & 21.94 \\
\hline & 8220 & Activities of call centres & 29212 & 67.3 \\
\hline & 4711 & $\begin{array}{l}\text { Retail sale in non-specialised stores with food, } \\
\text { beverages or tobacco predominating }\end{array}$ & 28014 & 7.57 \\
\hline
\end{tabular}

Continued 
Table 5 Continued

\begin{tabular}{|c|c|c|c|c|}
\hline $\begin{array}{l}\text { Autonomous } \\
\text { community }\end{array}$ & Code & Occupational activities & SA spells & SA/1000 affiliates \\
\hline & 9700 & $\begin{array}{l}\text { Activities of households as employers of domestic } \\
\text { personnel }\end{array}$ & 21385 & 20.93 \\
\hline & 8299 & Other business support service activities n.e.c & 20351 & 13 \\
\hline & 5630 & Beverage serving activities & 17608 & 12.05 \\
\hline & 4751 & Retail sale of textiles in specialised stores & 15735 & 15.31 \\
\hline \multirow[t]{10}{*}{ Region of Murcia } & 8620 & Medical and dental practice activities & 11008 & 34.8 \\
\hline & 0113 & $\begin{array}{l}\text { Growing of vegetables and melons, roots and } \\
\text { tubers }\end{array}$ & 7233 & 28.29 \\
\hline & 7820 & Temporary employment agency activities & 6037 & 23.35 \\
\hline & 4711 & General public administration activities & 6003 & 24.41 \\
\hline & 8121 & General cleaning of buildings & 4915 & 25.01 \\
\hline & 5610 & Restaurants and mobile food service activities & 3672 & 34.02 \\
\hline & 5630 & Beverage serving activities & 3635 & 21.63 \\
\hline & 4630 & Wholesale of food, beverage and tobacco & 3514 & 13.62 \\
\hline & 4711 & $\begin{array}{l}\text { Retail sale in non-specialised stores with food, } \\
\text { beverages or tobacco predominating }\end{array}$ & 3228 & 8.96 \\
\hline & 4923 & Freight transport by road & 2914 & 14.28 \\
\hline \multirow{10}{*}{$\begin{array}{l}\text { Chartered } \\
\text { Community of } \\
\text { Navarre }\end{array}$} & 8610 & Hospital activities & 14408 & 46.16 \\
\hline & 8411 & General public administration activities & 7408 & 57.01 \\
\hline & 2930 & $\begin{array}{l}\text { Manufacture of parts and accessories of motor } \\
\text { vehicles }\end{array}$ & 5782 & 18.2 \\
\hline & 7820 & Temporary employment agency activities & 5558 & 94.19 \\
\hline & 8521 & General secondary education & 3909 & 19.86 \\
\hline & 8121 & General cleaning of buildings & 3520 & 31.17 \\
\hline & 1030 & Processing and preserving of fruit and vegetables & 3256 & 38.37 \\
\hline & 2910 & Manufacture of motor vehicles & 3195 & 17.07 \\
\hline & 8812 & $\begin{array}{l}\text { Social work activities without accommodation for } \\
\text { the elderly and disabled }\end{array}$ & 3151 & 76.35 \\
\hline & 9700 & $\begin{array}{l}\text { Activities of households as employers of domestic } \\
\text { personnel }\end{array}$ & 2382 & 23.71 \\
\hline \multirow[t]{10}{*}{ La Rioja } & 8610 & Hospital activities & 1698 & 18.25 \\
\hline & 8611 & General public administration activities & 1612 & 22.76 \\
\hline & 1520 & Manufacture of footwear & 1463 & 38.2 \\
\hline & 8121 & General cleaning of buildings & 1290 & 29.05 \\
\hline & 1030 & Processing and preserving of fruit and vegetables & 1217 & 27.4 \\
\hline & 7820 & Temporary employment agency activities & 1060 & 71.12 \\
\hline & 2930 & $\begin{array}{l}\text { Manufacture of parts and accessories of motor } \\
\text { vehicles }\end{array}$ & 1006 & 12.1 \\
\hline & 5630 & Beverage serving activities & 973 & 14.3 \\
\hline & 1102 & Manufacture of wines & 962 & 13.09 \\
\hline & 0113 & $\begin{array}{l}\text { Growing of vegetables and melons, roots and } \\
\text { tubers }\end{array}$ & 907 & 21.5 \\
\hline \multirow[t]{2}{*}{ Valencia } & 8610 & Hospital activities & 24063 & 21.57 \\
\hline & 8611 & General public administration activities & 23311 & 24.51 \\
\hline
\end{tabular}

Continued 
Table 5 Continued

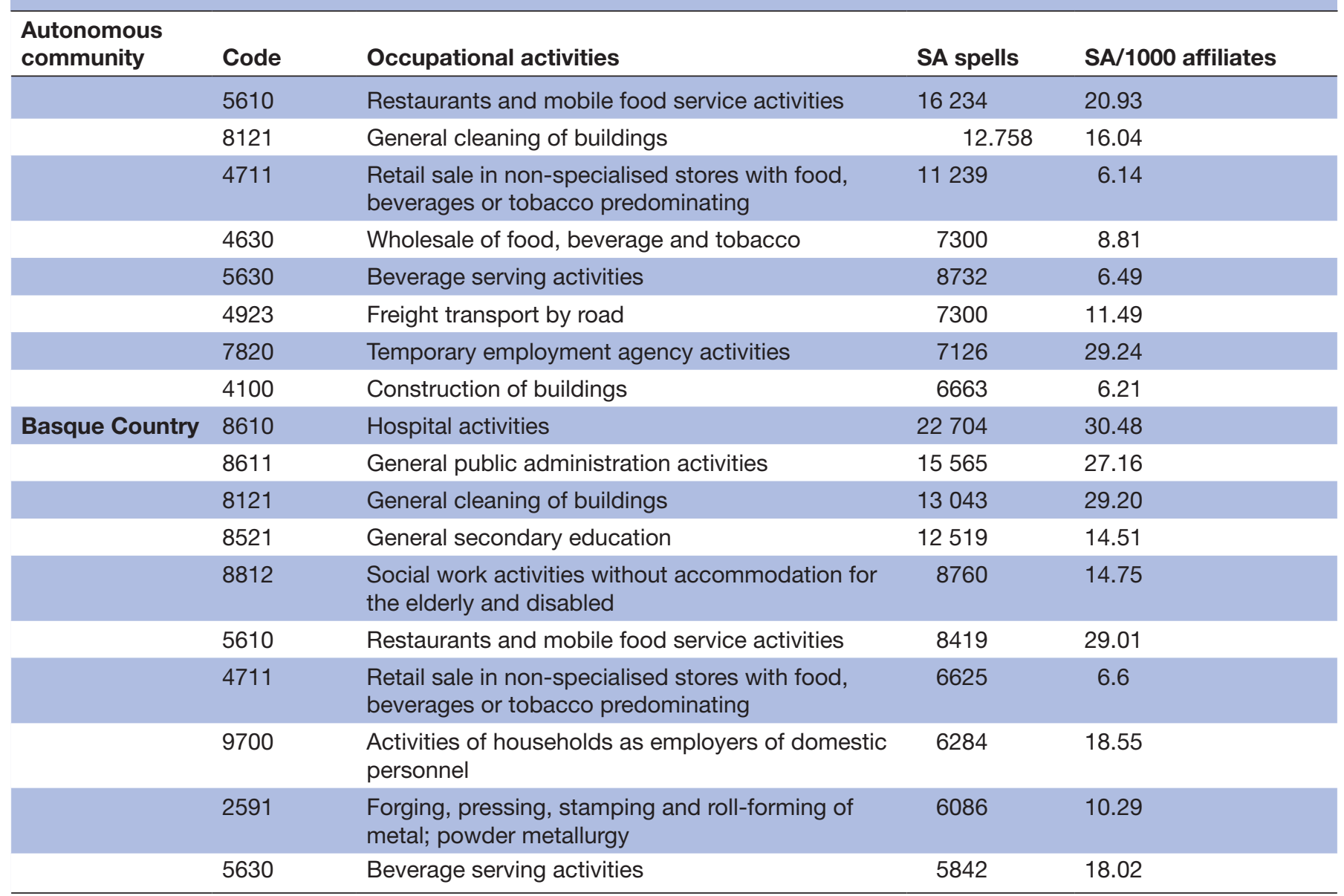

SA, sickness absence.

with that of other studies at the national ${ }^{4}$ and European ${ }^{19}$ level. Non-work-related SA showed a longer duration to work-related SA which has remained like this for years. ${ }^{14}$ The region that showed the shortest duration as a whole is Navarre, where the health expenditure per inhabitant is also the highest in Spain. Healthcare expenditure is also higher in the Basque Country, however, the duration of the it is one of the longest in many diagnostic chapters.

The most noteworthy fact is that the number of days on SA for self-employed workers is twice as much as for employees in all of Spain's regions. In our experience, this can be caused by the fact that self-employed workers do not usually start a process of short-term SA, because cash benefits for SA are paid 30 days after the start of SA and they do not receive cash benefits in short-term SA

The incidence, prevalence and average duration increase with age. This occurrs in all age ranges except for very young workers (men and women) and those over 65 years old. In young people it can be explained by the fact that they often have low-skilled jobs (they have not yet finished their education). They are often temporary and unstable jobs, and many young people work and study at the same time. This causes a double workload that could contribute to worsening their health. As it can be seen, they are short-term SA, which could indicate a low severity of the pathologies that produce them. In the over-65s the prevalence is very low in all regions. One possible explanation is that the retirement age in Spain is around 65 and the worker who decides to continue working instead of retiring is in good health. However, the duration of these SA is very long, because at this age there is a greater prevalence of serious pathologies (neoplasms, ictus, and so on).

The differences observed in the number of employees regarding sex are in line with the patterns obtained in other studies, with higher incidence ${ }^{19}$ and longer duration $^{21}$ in women. There is a sex breach in some European countries (Spain, Ireland, France, Belgium and UK) compared with others (Netherlands, Portugal and Italy). ${ }^{21}{ }^{22}$ The incidence increases with age, which is in agreement with most studies at the national ${ }^{423}$ and international ${ }^{71821-24}$ level, with higher intensity according to the number of affiliates per sex and age range (table 2). Among the multiple explanations for this fact, it is worth highlighting the following: the double work women usually carry out, that is, paid work and domestic work, with greater responsibilities for the family (traditional gender role), ${ }^{22}{ }^{24}$ the different behaviour of women toward disease, ${ }^{22}$ their greater morbidity related to maternity ${ }^{25}$ and more fragile health, ${ }^{26}$ as well as their lower 
commitment to work. ${ }^{22}$ Other authors highlight the occupational differences, which could explain more than half of the gender differences ${ }^{24}$ as well as the stress level. ${ }^{24}$ However, this gender breach is not constant in the longterm in all the European countries; ${ }^{21}{ }^{22}$ in fact, some studies question its existence based on the occupational level $^{27}$ and the stress level. ${ }^{28}$

The longest duration by diagnostic chapter is oncological diseases, cardiovascular diseases and mental disorders, which is in line with other studies. ${ }^{29-31}$ Moreover, this fact poses a serious problem of public health, given the accelerated increase of chronic diseases in all the countries around Spain, ${ }^{32}$ with the consequent increase in the incidence and duration of SA and the cost that it implies. ${ }^{42}$

The diagnosis that generated the largest number of SA cases, after the influenza, is lower back pain. This finding is in line with numerous studies, being, nationally, the main diagnosis of sick leave due to its high incidence and recurrence rate, ${ }^{33}$ as well as the duration ${ }^{23} 3435$ and economic costs of such SA. ${ }^{35}$ This is due to the great prevalence of such pathology, regardless of whether or not it generates SA cases, ${ }^{33} 36$ among other factors.

The Public Administration is in the first, second and third positions in the described ranking in almost all the regions. This can be explained by the difference between workers of the public sector, who represent a greater number of SA cases than employees in the private sector, as in other countries. ${ }^{19} 3738$ However, in previous studies carried out in Spain, the Public Administration did not represent or occupied such an important place in SA spells, being greatly surpassed by the industrial and construction sectors. ${ }^{16} 39$

When the SA spells are analysed by the number of affiliated workers in each occupational activities, a higher number of them is found in workers in call centres and temporary employment agencies. These activities have a high level of job instability, with a high worker turnover and very short-term contracts. ${ }^{40}$ This could explain the high rate of absence in them.

One of the occupational activities with the highest number of SA spells is retail sale in non-specialised stores with food, beverages or tobacco predominating, but when it is analysed by the number of affiliates, this number of SA spells is one of the lowest of all occupational activitiess. One possible explanation is that many of these workers are self-employed and, as mentioned before, in these workers the SA incidence is very low.

\section{CONCLUSION}

This study shows the important characteristics of SA in Spain. The most important differences are found in SA incidence and average duration between the different regions and non-work-related and work-related SA spells. There are also important differences in the number of SA spells between different occupational activities.
The regions that show the most difference SA are the Chartered Community of Navarre and the Community of Madrid. It would be interesting to carry out further studies that analyse the main factors that influence SA in Spain.

Acknowledgements We would like to thank the National Institute of Social Security for helping with the databases.

Contributors MLAJ, MJAB, NMM, MTLM and RMV conceived the original proposal and drafted the original manuscript. MLAJ, MJAB, NMM and RMV contributed to the development and refinement and statistical analysis of the protocol. All authors critically appraised the drafted manuscript and made important intellectual contributions to the writing. All authors have read and approved the final submitted manuscript.

Funding The University of Malaga through a predoctoral grant supports MLAJ, 900004852 a PhD student at the University.

Competing interests None declared.

Patient consent for publication Not required.

Ethics approval This project was approved by Andalusia Ethics Committee (ID900004852).

Provenance and peer review Not commissioned; externally peer reviewed.

Data availability statement Data are available in a public, open access repository. All data relevant to the study are included in the article or uploaded as supplementary information. All data relevant to the study are included in the article. Data are available in a public, open access repository: http://www.seg-social.es/ wps/portal/wss/internet/EstadisticasPresupuestosEstudios/

Open access This is an open access article distributed in accordance with the Creative Commons Attribution Non Commercial (CC BY-NC 4.0) license, which permits others to distribute, remix, adapt, build upon this work non-commercially, and license their derivative works on different terms, provided the original work is properly cited, appropriate credit is given, any changes made indicated, and the use is non-commercial. See: http://creativecommons.org/licenses/by-nc/4.0/.

ORCID iD

Rocío Martín-Valero http://orcid.org/0000-0002-1664-3647

\section{REFERENCES}

1 Spasova S, Bouget D, Vanhercke B. Sick pay and sickness benefit schemes in the European Union. Background report for the Social Protection Committee's In-Depth Review on sickness benefits 2016.

2 Ministerio de Trabajo, M. y S. S. Presupuestos de la Seguridad social, 2019.

3 Lusinyan L, Bonato L. Work absence in Europe. IMF Staff Pap 2007;54:475-538.

4 Alba-Ramírez A. La incapacidad temporal para El trabajo: análisis económico de SU incidencia Y SU duración. 150. Madrid: Univ Carlos III, 2009.

5 Peña Longobardo LM, Reneo A, I, Oliva-Moreno J, et al. Evaluación de las pérdidas laborales provocadas Enfermedades $Y$ lesiones en España en El año 2009. Rev Evaluación Programas y Políticas Públicas 2016;1:66.

6 Helgesson M, Johansson B, Nordqvist T, et al. Sickness absence at a young age and later sickness absence, disability pension, death, unemployment and income in native Swedes and immigrants. Eur J Public Health 2015;25:688-92.

7 Virtanen M, Kivimäki M, Vahtera J, et al. Sickness absence as a risk factor for job termination, unemployment, and disability pension among temporary and permanent employees. Occup Environ Med 2006;63:212-7.

8 Salonen L, Blomgren J, Laaksonen M, et al. Sickness absence as a predictor of disability retirement in different occupational classes: a register-based study of a working-age cohort in Finland in 20072014. BMJ Open 2018;8:e020491.

9 Bryngelson A. Long-Term sickness absence and social exclusion. Scand J Public Health 2009;37:839-45.

10 Ferrie JE, Vahtera J, Kivimäki M, et al. Diagnosis-specific sickness absence and all-cause mortality in the GAZEL study. J Epidemiol Community Health 2009;63:50-5. 
11 Kivimäki M, Head J, Ferrie JE, et al. Sickness absence as a global measure of health: evidence from mortality in the Whitehall II prospective cohort study. BMJ 2003;327:364-8.

12 Gjesdal S, Ringdal PR, Haug K, et al. Mortality after long-term sickness absence: prospective cohort study. Eur J Public Health 2008;18:517-21.

13 Gimeno D, Benavides FG, Benach J, et al. Distribution of sickness absence in the European Union countries. Occup Environ Med 2004;61:867-9.

14 Benavides FG, Torá I, Miguel Martínez J, et al. Evaluación de la gestión de Los casos de incapacidad temporal POR contingencia común de más de 15 días en Cataluña. Gac Sanit 2010;24:215-9.

15 Vicente-Herrero MT, Terradillos García MJ, Capdevila Garcia LM, et al. [Sick leaves caused by psychiatric diseases in Spain during 2011]. Rev Med Chil 2013;141:248-54.

16 Benavides FG, Plana M, Serra C, et al. [Return to work after a nonwork related sick spell: the role of age, sex, economic activity and autonomous community]. Rev Esp Salud Publica 2007;81:183-90.

17 Cuesta M. Tasas de absentismo POR enfermedad en Epaña: datos para El periodo 1996-2004. Cuad Econ 2012;35:1-8.

18 Livanos L, Zangelidis A. Sickness absence: a pan-European study. Munich Pers RePEc Arch 2010.

19 Rosta J, Tellnes G, Aasland OG. Differences in sickness absence between self-employed and employed doctors: a cross-sectional study on national sample of Norwegian doctors in 2010. BMC Health Serv Res 2014;14:1-8.

20 Alba-Ramírez A, López-Mourelo E. Sickness absence from work in Spain: are there gender differences? UC3M Work Pap 2017:15-17.

21 Pekkala J, Blomgren J, Pietiläinen O, et al. Occupational class differences in long sickness absence: a register-based study of 2.1 million Finnish women and men in 1996-2013. BMJ Open 2017; 7:e014325.

22 Mastekaasa A. The gender gap in sickness absence: longterm trends in eight European countries. Eur J Public Health 2014;24:656-62.

23 Álvarez Theurer E, Llergo Muñoz A, Vaquero Abellán M. Análisis de la duración de Los períodos de incapacidad temporal POR procesos en Andalucía. Factores asociados. Atención Primaria 2009;41:387-93.

24 Laaksonen M, Mastekaasa A, Martikainen P, et al. Gender differences in sickness absence--the contribution of occupation and workplace. Scand J Work Environ Health 2010;36:394-403.

25 Ariansen AMS. Age, occupational class and sickness absence during pregnancy: a retrospective analysis study of the Norwegian population registry. BMJ Open 2014;4:e004381.

26 Fuentes M, Ojuel J, Llobet CV, Banqué M. Morbilidad diferencial entre mujeres Y hombres. Anu Psicol 2008;39:9-22.
27 Løset GK, Dale-Olsen H, Hellevik T, et al. Gender equality in sickness absence tolerance: attitudes and norms of sickness absence are not different for men and women. PLoS One 2018;13:e0200788.

28 Mastekaasa A, Melsom AM. Occupational segregation and gender differences in sickness absence : Evidence from 17 European countries Acknowledgement: We are grateful to the European Commission Eurostat and to the original collecting agencies for access to the EU LFS 2008.

29 Ármannsdóttir B, Mårdby A-C, Haukenes I, et al. Cumulative incidence of sickness absence and disease burden among the newly sick-listed, a cross-sectional population-based study. BMC Public Health 2013;13:329.

30 Zhang W, McLeod C, Koehoorn M. The relationship between chronic conditions and absenteeism and associated costs in Canada. Scand $J$ Work Environ Health 2016;42:413-22.

31 Jakovljevic M, Malmose-Stapelfeldt C, Milovanovic O, et al. Disability, work absenteeism, sickness benefits, and cancer in selected European OECD Countries - Forecasts to 2020. Front Public Health 2017;5:1-8.

32 Nexo MA, Carlsen K, Pedersen J, et al. Long-Term sickness absence of 32 chronic conditions: a Danish register-based longitudinal study with up to 17 years of follow-up. BMJ Open 2018;8:e020874.

33 Hestbaek L, Leboeuf-Yde C, Manniche C. Low back pain: what is the long-term course? A review of studies of general patient populations. Eur Spine J 2003;12:149-65.

34 Steenstra IA, Verbeek JH, Heymans MW, et al. Prognostic factors for duration of sick leave in patients sick listed with acute low back pain: a systematic review of the literature. Occup Environ Med 2005;62:851-60.

35 Diaz-Ledezma C, Urrutia J, Romeo J, et al. Factors associated with variability in length of sick leave because of acute low back pain in Chile. Spine J 2009;9:1010-5.

36 Crook J, Milner R, Schultz IZ, et al. Determinants of occupational disability following a low back injury: a critical review of the literature. J Occup Rehabil 2002;12:277-95

37 Oke A, Braithwaite P, Antai D. Sickness absence and precarious employment: a comparative cross-national study of Denmark Finland, Sweden, and Norway. Int J Occup Environ Med 2016;7:125-47.

38 Alexopoulos EC, Merekoulias G, Tanagra D, et al. Sickness absence in the private sector of Greece: comparing shipyard industry and national insurance data. Int J Environ Res Public Health 2012;9:1171-81.

39 G Benavides F, Zaballa E, Duran X, et al. [Incidence of non-workrelated sickness absence in Spain by economic activity of the company]. Arch Prev Riesgos Labor 2017;20:14-25.

40 Micheli Thirión J. Los call centers Y Los nuevos trabajos del siglo XXI. Confin Relac Int y Cienc política 2007;3. 